慶應義塾大学学術情報リポジトリ

Keio Associated Repository of Academic resouces

\begin{tabular}{|c|l|}
\hline Title & $\begin{array}{l}\text { In vitro studies of the effects of naloxone on the root potentials in the frog spinal cord: } \\
\text { enkephalin-like effect on the recurrent presynaptic inhibition }\end{array}$ \\
\hline Sub Title & \\
\hline Author & $\begin{array}{l}\text { 鈴木, 岳之(Suzuki, Takeshi) } \\
\text { 岡, 淳一郎(Oka, Junichiro) } \\
\text { 福田, 英臣(Fukuda, Hideomi) }\end{array}$ \\
\hline Publisher & 共立薬科大学 \\
\hline Publication year & 1987 \\
\hline Jtitle & $\begin{array}{l}\text { 共立薬科大学研究年報 (The annual report of the Kyoritsu College of } \\
\text { Pharmacy). No.32 (1987.),p.73-73 }\end{array}$ \\
\hline JaLC DOI & \\
\hline Abstract & \\
\hline Notes & 抄録 \\
\hline Genre & Technical Report \\
\hline URL & https://koara.lib.keio.ac.jp/xoonips/modules/xoonips/detail.php?koara_id=AN00062898-0000003 \\
2-0073
\end{tabular}

慶應義塾大学学術情報リポジトリ(KOARA)に掲載されているコンテンツの著作権は、それぞれの著作者、学会または出版社/発行者に帰属し、その権利は著作権法によって 保護されています。引用にあたっては、著作権法を遵守してご利用ください。

The copyrights of content available on the KeiO Associated Repository of Academic resources (KOARA) belong to the respective authors, academic societies, or publishers/issuers, and these rights are protected by the Japanese Copyright Act. When quoting the content, please follow the Japanese copyright act. 


\title{
In Vitro Studies of the Effects of Naloxone on the Root Potentials in the Frog Spinal Cord: Enkephalin-like Effect on the Recurrent Presynaptic Inhibition
}

\author{
Takeshi Suzukı, Jun-ichiro OKa* and Hideomi FukudA* \\ 鈴木岳之, 岡 淳一郎*, 福田英臣*
}

1. Specific binding of $\left[{ }^{3} \mathrm{H}\right]$ naloxone was demonstrated in the frog spinal cord.

2. In isolated and perfused frog spinal cord, naloxone increased the spontaneous discharges of the ventral root.

3. Naloxone decreased the ventral root-dorsal root potential (VR-DRP) in a dosedependent manner, and inhibited presynaptic inhibition of the ventral root reflex.

4. Methionine-enkephalin also decreased the VR-DRP, and naloxone partially antagonized this effect.

5. These results suggest the existence of enkephalinergic control of spinal motor activities and that naloxone has a partial agonistic effect in the frog spinal cord.

本報告は Comp. Biochem. Physiol., 87 C, 221-225（1987）に発表.]

* 東京大学薬学部 